\title{
Molecular Virology
}

National Cancer Institute

\section{Source}

National Cancer Institute. Molecular Virology. NCI Thesaurus. Code C18887.

The study of viral processes at the molecular level. Includes infection, replication, and expression of the viral genome. 